

\section{DISCLAIMER}

This report was prepared as an account of work sponsored by an agency of the United States Government. Neither the United States Government nor any agency Thereof, nor any of their employees, makes any warranty, express or implied, or assumes any legal liability or responsibility for the accuracy, completeness, or usefulness of any information, apparatus, product, or process disclosed, or represents that its use would not infringe privately owned rights. Reference herein to any specific commercial product, process, or service by trade name, trademark, manufacturer, or otherwise does not necessarily constitute or imply its endorsement, recommendation, or favoring by the United States Government or any agency thereof. The views and opinions of authors expressed herein do not necessarily state or reflect those of the United States Government or any agency thereof. 


\section{DISCLAIMER}

Portions of this document may be illegible in electronic image products. Images are produced from the best available original document. 


\section{LEGAL NOTICE}

This report was prepared as an account of Government sponsored work. Neither the United States, nor the Commission, nor any person acting on behalf of the Commission:

A. Makes any warranty or representation, expressed or implied, with respect to the accuracy, completeness, or usefulness of the information contained in this report, or that the use of any information, apparatus, method, or process disclosed in this report may not infringe privately owned rights; or

B. Assumes any liabilities with respect to the use of, or for damages resulting from the use of any information, apparatus, method, or process disclosed in this report.

As used in the above, "person acting on behalf of the Commission" includes any employee or contractor of the Commission, or employee of such contractor, to the extent that such employee or contractor of the Commission, or employee of such contractor prepares, disseminates, or provides access to, any information pursuant to his employment or contract with the Commission, or his employment with such contractor.

Printed in the United States of America

Available from

Clearinghouse for Federal Scientific and Technical Information

National Bureau of Standards, U. S. Department of Commerce

Springfield, Virginia 22151

Price: Printed Copy $\$ 3.00 ;$ Microfiche $\$ 0.65$ 


\title{
DISPOSAL OF FLUORINE
}

\author{
James D. Novratil
}

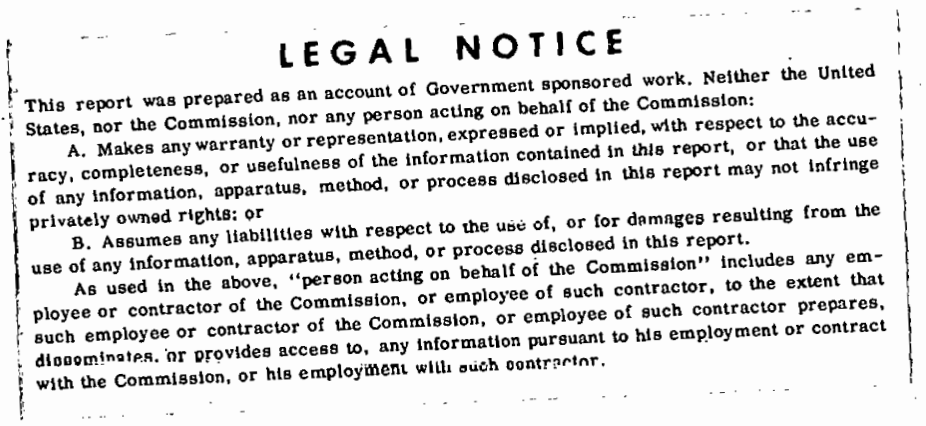

THE DOW CHEMICAL COMPANY ROCKY FLATS DIVISION

P. O. BOX 888

GOLDEN, COLORADO 80401

U. S. ATOMIC ENERGY COMMISSION CONTRACT AT(29-1)-1106 
RFP-1200 


\section{CONTENTS}

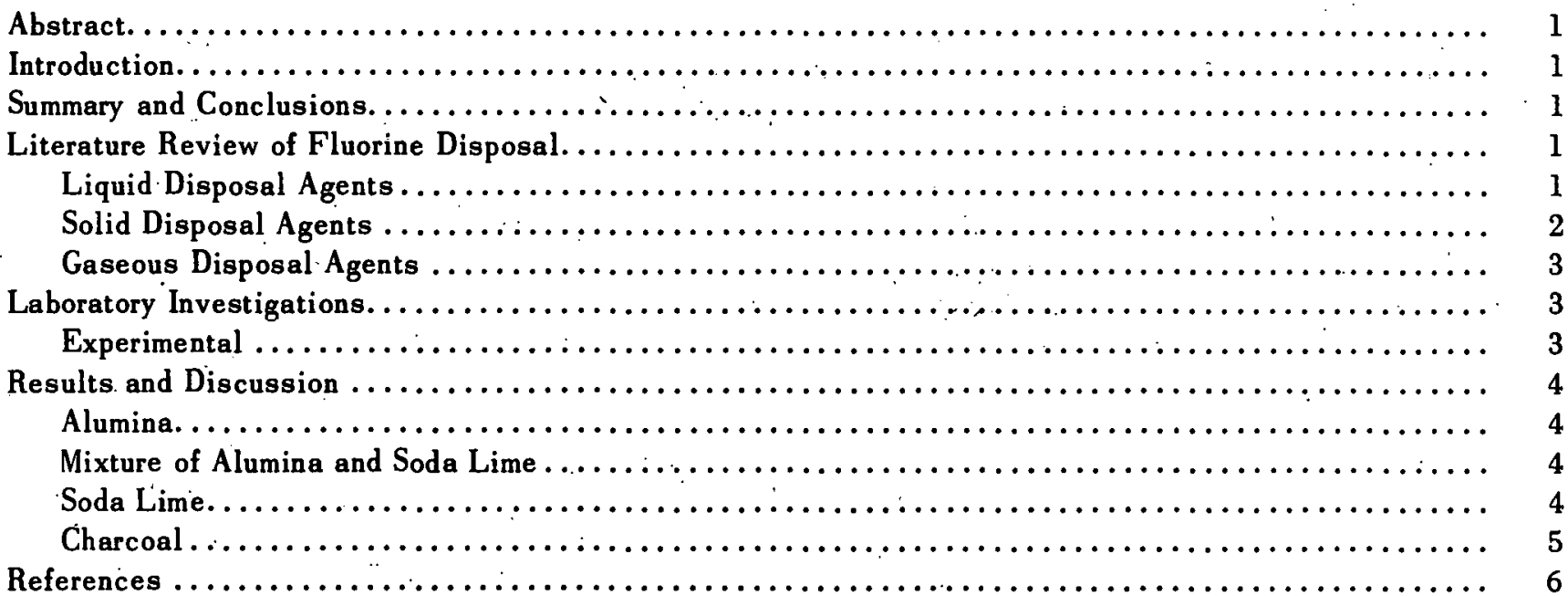




\section{A CK N OWLEDGMENTS}

'I'he author wishes to thank Mrs. 'I'. Lockaby and Mrs. J. Lockwood for their assistance in gathcring numerous reports and articles. I also acknowledge the assistance of J. M. Cileveland and K. S. Marshall in preparing this report.

The experimental fluorine disposal data were obtained by G. F. Molen, J. D. Moseley, H. N. Robinson, and R. 0 . Wing. 


\section{Disposal of Fluorine}

James D: Navratil

\begin{abstract}
A literature review of fluorine disposal systems is presented. The review, containing 44 references, is complete as of April l, 1968.
\end{abstract}

Experimental work on fluorine disposal at Rocky Flats is also presented. Alumina, soda lime, and charcoal were evaluated as fluorine disposal media. Plugging of the disposal traps occurred regularly when alumina and soda lime were used. The use of charcoal reduced plugging problems, but a check valve was required to eliminate interference from small pressure surges resulting from the charcoal-fluorine reaction. In a given size trap, charcoal had twice the fluorine capacity for fluorine disposal, as compared to soda-lime or alumina capacity.

\section{INTRODUCTION}

A fluoride volatility process to recover plutonium from residues is now under development at Rocky Flats. A fluorine disposal system is needed to dispose of fluorine not consumed in the process.

This report reviews the fluorine disposal systems described in the literature and evaluates the disposal systems investigated at Rocky Flats.

\section{SUMMARY AND CONCLUSIONS}

Fluorine disposal systems utilizing liquids, solids, and gases have been described in the literature. Caustic solutions and water were frequently mentioned. Sodium hydroxide solution was the most desirable liquid agent, especially when $\mathrm{CaO}$ was added to regenerate $\mathrm{NaOH}$. A review of media used for solid disposal included charcoal, alumina, soda lime, and several other less efficient agents. Stalic beds of cucoñut charcual and fluid beds of activated alumina were reported to be highly effective fluorine disposal systems. No explosions were encountered with the use of charcoal. When burning fluorine with hydrocarbons it is necessary to dispose of the HF product.

Ammonia was effective when a water spray was utilized.
Static-bed disposal traps constructed of copper and Monel were used to evaluate activated alumina, soda lime, and charcoal as fluorine disposal agents. Exhaust line plugging occurred when alumina was used as the disposal medium. Plugging problems were less severe when soda lime was used. Water evolved during the fluorine-soda lime reaction but it presented no problems. The use of wood charcoal eliminated plugging problems, but pressure surges were noted during the reaction. A check valve upstream from the disposal trap prevented interference on the upstream system from the trap. Charcoal was selected as the most desirable disposal medium because of its high disposal capacity, gaseous reaction product $\left(\mathrm{CF}_{4}\right)$, and freedom from trap plugging.

From the literature review and experimental data, three recommendations for fluorine disposal at Rocky Flats are proposed:

1. Since uranium dioxide has been reported as an efficient fluorine disposal reagent, plutonium dioxide should be evaluated for the same purpose.

2. Coconut charcoal is the most desirable solid disposal medium other than plutonium dioxide.

3. If caustic scrubbing is used, calcium oxide should be added to regenerate the sodium hydroxide.

\section{LITERATURE REVIEW OF FLUORINE DISPOSAL}

A review of liquid, solid, and gaseous disposal media for fluorine is presented. The review, containing 44 references, was complied from references in Chemical Abstracts and Nuclear Science Abstracts and is current to April 1, 1968.

Liquid Disposal Agents: Several spray towers and absorption devices utilizing liquid agents for fluorine disposal have been described (1-8). One such agent, water, has been thoroughly studied. Slabey and Fletcher (9) reported that the fluorinewater reaction was inefficient at $35^{\circ} \mathrm{C}$. Others 
reported that the reaction was explosive at times $(10,11)$. Steam was reacted with fluorine in several pilot plant operations $(12,13)$. Smiley and Schmitt (14) reported a continuous process for the disposal of fluorine using steam. This process consists of reacting a $\mathrm{F}_{2}-\mathrm{N}_{2}$ mixture $\left(13-75 \% \mathrm{~F}_{2}\right)$ with a 200 to $2900 \%$ excess of steam at 500 to $750^{\circ} \mathrm{F}$. The reaction released large quantities of heat, but no explosions were encountered. Equipment constructed of Monel was used.

Descriptions of caustic-scrubbing disposal towers for fluorine have been reported (15-17). Landau and Rosen (18) designed a continuous fluorine disposal apparatus using a 5 to $10 \%$ sodium hydroxide solution heated to $100-150^{\circ} \mathrm{F}$. This apparatus utilized a carbon brick-lined reactor, and the exhaust gas contained only $3 \mathrm{ppm} \mathrm{F}_{2}$. The effluent liquid was treated with an excess of $\mathrm{CaO}$ slurry to regenerate the $\mathrm{NaOH}$ and precipitate $\mathrm{CaF}_{2}$. This regeneration using $\mathrm{CaO}$ prevented plugging and corrosion of equipment. The lime slurry addition was also described by Maier (19), and its use provided a cost savings.

Other fluorine disposal solutions included $\mathrm{Na}_{2} \mathrm{CO}_{3}$, $\mathrm{NH}_{4} \mathrm{OH}$, and $\left(\mathrm{NH}_{4}\right)_{2} \mathrm{CO}_{3}(20,21)$. Fichter and Goldach (2i) studied the reaction of various concentrations of $\mathrm{NH}_{4} \mathrm{OH}$ and $\left(\mathrm{NH}_{4}\right)_{2} \mathrm{CO}_{3}$ solutions with fluorine at several temperatures. Results are given of the analyses of the reaction products. Aluminum hydroxide was reported to remove fluorine in waste gases (22). This process was developed to recover fluorine in the electrolytic production of aluminum, and was greater than $98 \%$ efficient.

Solid Disposal Agents: The reaction between fluorine and graphite has been thoroughly investigated (23-29). Ruff and Bretschneider (23) studied the fluorine-graphite reaction, and reported that graphite was attacked only above $420^{\circ} \mathrm{C}$ by fluorine and forms carbon monofluoride. From 460$700^{\circ} \mathrm{C}$ this reaction was sometimes explosive, and above $700^{\circ} \mathrm{C}$ graphite burned in fluorine to produce mostly $\mathrm{CF}_{4}$. Kuriakose and Margrave (28) studied the kinetics of the fluorine-graphite reaction and reported graphite gained fluorine weight between 315 and $530^{\circ} \mathrm{C}$ and lost weight above $600^{\circ} \mathrm{C}$ with the formation of gaseous fluorides. No explosive reactions were mentioned. Schmidt $(30,31)$ reported the design and operational criteria for fluorine disposal with charcoal. The essence of his study is as follows: The disposal-rate limit was found to be inversely proportional to the charcoal-bed particle diameter. Fluorine dilution and moisture content of the charcoal do not affect the reaction. In a carbon-lined vessel containing 6 cubic feet of charcoal, up to 25 pounds per hour of fluorine could be reacted. Cooling this reactor caused channeling of the fluorine. The exhaust gases contained less than $77.5 \mathrm{ppm}$ of fluorine, and no explosive reactions were encountered in disposing of over 150 pounds of fluorine.

Wood, coke, and coconut-shell charcoals were evaluated for fluorine consumption by Houston (32). Houston reported that coconut-shell charcoal produced the smallest amount of solid and liquid reaction products. Effective fluorine removal from a $25 \%$ fluorine-75\% nitrogen mixture was accomplished by all three types of charcoal in a one-half-inch-diameter, 16-inch-long reactor at flow rates from 100 to 400 $\mathrm{scfh}$. The reaction temperature was found to be a-function of the amount of fluorine introduced, and temperatures between 1200 and $1800^{\circ} \mathrm{F}$ were recorded. Mesh sizes investigated proved efficient. The reaction between the coconut-shell charcoal and fluorine produced "pings" which were the ignition of several partially charred, charcoal lumps containing volatiles. No explosions from carbon monofluoride were encountered.

Holmes and Schoffstoll (33) investigated fluorine disposal efficiency in a 24 inch by 2 inch diameter nickel reactor using a fluidized bed of activated alumina (Alcoa grade F-1). The alumina-fluorine reaction proved $99.99 \%$ efficient in removing the fluorine, and the capacity of the alumina was $0.8 \mathrm{~g}$ $\mathrm{F}_{2}$ per gram of activated alumina (34).

Sodium chloride reacts with fluorine to produce sodium fluoride and chlorine. A small amount of sodium fluoride at the reactor inlet ensures completeness of the fluorine-salt reaction (35).

Sorption of halogen gases from air using limestone has been reported $(36,37)$. A 4-foot depth of limestone was required to remuve $96 \%$ of the fluorine and a 9-foot depth was required for complete recovery of the fluorine at velocities of 0.6 to 1.5 feet/ second (37). In another study (34), with a fluorine breakthrough defined at $200 \mathrm{ppm} \mathrm{F}_{2}$, the capacity to dispose of fluorine was only $0.045 \mathrm{~g} \mathrm{~F}_{2} / \mathrm{g}$ limestone ( $12 \%$ theoretical).

Argonne National Laboratory reported using sodium carbonate to dispose of fluorine (34). The efficiency 
of this agent was $0.32 \mathrm{~g} \mathrm{~F}_{2} / \mathrm{g} \mathrm{Na}_{2} \mathrm{CO}_{3}$ which is $90 \%$ of the theoretical capacity of sodium carbonate.

Additional solid agents reported for fluorine disposal are silica gel and uranium tetrafluoride (38-41). Silica gel was used for absorbing gases containing fluorine in the superphosphate industry, but the use of this method requires conversion to HF. A fluidized bed of $\mathrm{UF}_{4}$ was used to recover fluorine in the production of $U_{6}$ and was reported as $98 \%$ efficient at $700-750^{\circ} \mathrm{F}$ in recovering fluorine (41).

Gaseous Disposal Agents: A scrub-tower which removes halogen off-gases by reaction with anhydrous ammonia has been developed (42). The reaction products were mostly ammonium halide smoke which was dissolved and removed by a water spray. Analysis of the off-gas from the scrubtower has shown efficiency to be nearly $100 \%$.

Turnbull, et al.(43), have investigated the disposal of fluorine with carbon, sulfur, and hydrogen, but found that the most efficient agent was propane or butane. A water or caustic scrubber was used to dispose of the reaction products when fluorine was burned on a large scale. A small 4-inch ring burner gave a burning capacity of 4.5 pounds of fluorine per hour. Long (44) reports a system in which fluorine was burned in a coal-gas flame, and the combustion products were adsorbed in a caustic solution. Flow rates up to 15 liters per hour have been handled on this system.

Fluorine was reported to react with hydrogen to yield gentle explosions accompanied by the evolution of heat (10). Burning occurred during the reaction but it was not spontaneous. No further details were given.

\section{LABORATORY INVESTIGATIONS}

Several static-led fluoriue dispusul thaps were evaluated in conjunction with plutonium fluorination experiments conducted at Roeky Flats. This section contains the results from using alumina, soda lime, and charcoal as disposal reagents.

Experimental: The fluorine disposal traps were part of a static-bed flunride volatility system. The traps were fabricated either from copper or Monel and were approximately 3 inches in diameter by 13inches long with a void volume of 1.4 liters.

Fluorine at approximately atmospheric pressure entered the bottom of each trap as illustrated in Figure 1, and was regulated through a Brooks $(100-500 \mathrm{cc} / \mathrm{min}$.$) rotometer. The traps were$ operated both in parallel and series.

A halogen detection device was located at the trap outlet. This device consisted primarily of a nylon string which could break and activate an alarm. Paper saturated with KI solution was also used to detect fluorine in the exhaust gases.

Thermocouples were taped to the bottom and/or middle of each trap. A Dynalog multiple temperature recorder was used to record the trap temperature.

The specifications of the activated alumina, soda lime, and charcoal disposal reagents are presented in Table I.

Figure 1. Fluorine disposal apparatus.

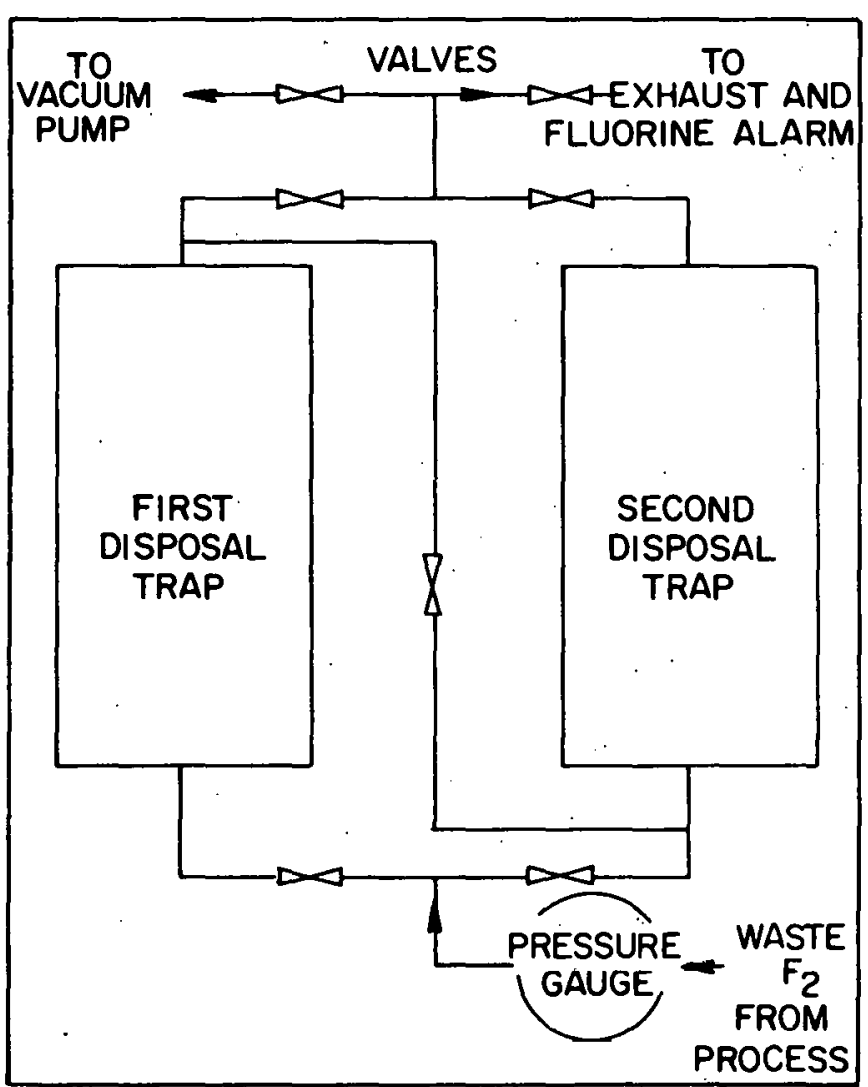


Table I. Specifications of fluorine disposal reagents.

\begin{tabular}{|c|c|c|c|c|}
\hline $\begin{array}{c}\text { Fluorine } \\
\text { Disposal } \\
\text { Reagent }\end{array}$ & $\begin{array}{l}\text { Manufacturer } \\
\text { and Grade }\end{array}$ & $\begin{array}{l}\text { Mesh } \\
\text { Size }\end{array}$ & $\begin{array}{c}\text { Bulk } \\
\text { Dẹnsity } \\
(\mathrm{g} / \mathrm{cc})\end{array}$ & $\begin{array}{c}\text { Special } \\
\text { Conditioning }\end{array}$ \\
\hline $\begin{array}{l}\text { Activated } \\
\text { Alumina }\end{array}$ & Alcon & $1 / 2-4$ & 0.98 & None \\
\hline $\begin{array}{l}\text { Soda lime } \\
(\mathrm{CaO}+\mathrm{NaOH})\end{array}$ & $\begin{array}{l}\text { W. R. Grace } \\
\text { \& Co. } \\
\text { Sodasorb brand }\end{array}$ & $4-8$ & 0.76 & $\begin{array}{l}\text { Dried to } \\
\text { remove } 14-19 \% \\
\text { water }\end{array}$ \\
\hline Charcoal & $\begin{array}{l}\text { Cliffs-Dow } \\
\text { Chemical Co. } \\
\text { Cliffchar } \\
\text { Activated } \\
\text { Carbon }\end{array}$ & $4-10$ & 0.21 & Rescreened \\
\hline
\end{tabular}

\section{RESULTS AND DISCUSSION}

\begin{abstract}
Alumina: Disposal traps constructed of copper were filled with activated alumina and run in series for these experiments. Three tests were conducted and each test was terminated because the outlet of the first trap plugged. The material plugging the outlet was identified by $x$-ray diffraction as nickel and copper chlorides. The chlorine source was probably an impurity in either the disposal reagent or the plutonium dioxide feed. The trap was refilled with alumina after each plugging incident.
\end{abstract}

A maximum of 1.4 moles of fluorine per mole of alumina was disposed as shown in Table II. Identification by $x$-ray diftraction of the used alumina on the bottom half of the trap revealed the major constituent as $\mathrm{AlF}_{3}$ and the minor constituent as $\mathrm{Al}_{2} \mathrm{O}_{3} \cdot \mathrm{H}_{2} \mathrm{O}$. The top half of the used alumina primarily consisted of $\mathrm{Al}_{2} \mathrm{O}_{3} \cdot \mathrm{H}_{2} \mathrm{O}$ and $\mathrm{Al}_{2} \mathrm{O}_{3}$.

The maximum temperature recorded on the wall of the trap was approximately $100-105^{\circ} \mathrm{C}$, but higher temperatures probably existed inside. The temperature was highest at the bottom of the first trap.

Mixture of Alumina and Soda Lime: A second series of experiments was conducted with the copper traps arranged in parallel. In the first trap a $1: 1$ volume ratio of alumina and soda lime was used. The second trap contained only soda lime. A layer of nickel chips was placed above and below both reagents to prevent fines from leaving the traps.

Table II shows the efficiency results and Table III compares the maximum temperature of both traps.
Table II. Summary of fluorine disposal reagent efficiency.

\begin{tabular}{|c|c|c|c|c|}
\hline $\begin{array}{c}\text { Disposal } \\
\text { Reagent }\end{array}$ & $\begin{array}{c}\text { Moles of } \\
\text { Disposal } \\
\text { Reagent }\end{array}$ & $\begin{array}{l}\text { Moles of } \\
\text { Fluorine } \\
\text { Disposed }\end{array}$ & $\begin{array}{c}\text { Moles Fluorine } \\
\text { per } \\
\text { Mole Reagent }\end{array}$ & $\begin{array}{l}\text { Reason for } \\
\text { Termination }\end{array}$ \\
\hline Alumina & 13 & 17 & 1.3 & Plugging \\
\hline Alumina & 13 & 13 & 1.0 & Plugging \\
\hline Alumina & 13 & 18 & 1.4 & Plugging \\
\hline $\begin{array}{l}\text { Alumina- } \\
\text { Soda lime* } \\
\quad-\end{array}$ & 16 & 11 & 0.7 & Plugging \\
\hline Soda lime & 20 & 19 & 1.0 & Plugging \\
\hline Soda lime & 20 & 17 & 0.9 & $F_{2}$ Breakthrough \\
\hline Soda lime & 20 & 19 & 1.0 & $F_{2}$ Breakthrough \\
\hline Charcoal & 27 & 32 & 1.2 & Plugging \\
\hline Charcoal & 13 & 17 & 1.3 & - Plugging \\
\hline Charcoal & 24 & 27 & 1.1 & Plugging \\
\hline Charcoal & 21 & 25 & 1.2 & Refill Charcoal \\
\hline Charcoal & 27 & $34^{\circ}$ & 1.3 & Plugging \\
\hline
\end{tabular}

*NOTE: 'lraps not run in series.

Table III. Comparison of the maximum trap wall temperature using soda lime-alumina mixture and soda lime.

$\begin{array}{cccc}\begin{array}{c}\text { Fluorination } \\ \text { Time }(\mathrm{hr})\end{array} & \begin{array}{c}\text { Fluorine } \\ \text { Flow-Rate } \\ (\mathrm{cc} / \mathrm{min})\end{array} & \begin{array}{c}\text { Temperature of } \\ \text { Soda Lime-Alumina } \\ \text { Mixture }\left({ }^{\circ} \mathrm{C}\right)\end{array} & \begin{array}{c}\text { Temperature of } \\ \text { Soda Lime }\left({ }^{\circ} \mathrm{C}\right)\end{array} \\ 1 & 250 & 90 & 85 \\ 2 & 400 & 140 & 75 \\ 1 & 550 & 130 & 80 \\ 2 & 550 & 120 & 80\end{array}$

Although the first trap appears to operate at higher temperatures than the second, this could be due to more fluorine entering the first trap.

After 11.2 moles of fluorine had been consumed by the two traps in parallel, the first trap (containing alumina-soda lime mixture) plugged. Some of the nickcl chips in the plugged trap had been converted to a greenish-white powder, presumably nickel fluoride, which was suspected of causing the plugging.

Soda Lime: Traps constructed of Monel were used to evaluate soda lime $(\mathrm{CaO}+\mathrm{NaOH})$ as a fluorine disposal medium. Each trap contälned approximately $1 \mathrm{~kg}$ of soda lime which had been dried overnight at $100-150^{\circ} \mathrm{C}$. In spite of drying, water (presumably from water of hydration) flowed out of the exhaust tube after approximately 2 moles of fluorine had been disposed. 
The traps were arranged in series because when they were run in parallel, fluorine was detected in the exhaust gases. In three experiments, a maximum of 19 moles of fluorine was disposed of, as shown in Table II. These experiments were terminated primarily because of fluorine breakthrough. Line plugging appeared less severe with soda lime than with alumina.

As presented in Table IV, the wall temperature of the first trap exceeded $200^{\circ} \mathrm{C}$ after disposing of approximately 2 moles of fluorine. The trap temperature at the base decreased with fluorine disposed. This was probably caused by the rising reaction zone in the trap. (Thermocouples were located at the base of each trap.)

Table IV. Bottom wall temperature of traps fill with soda lime.

Flow rate: $400 \mathrm{cc} / \mathrm{min}$.

$\begin{array}{ccc}\begin{array}{c}\text { Moles of } \\ \text { Fluorine Disposed }\end{array} & \begin{array}{c}\text { Maximum Temperature } \\ \left.\text { of First Trap }{ }^{\circ} \mathrm{C}\right)\end{array} & \begin{array}{c}\text { Maximum Temperature } \\ \text { of Second Trap }\left({ }^{\circ} \mathrm{C}\right)\end{array} \\ 2 & >200^{*} & >200^{*} \\ 5 & 175 & 60 \\ 10 & 125 & 54 \\ 15 & 70 & 57\end{array}$

*NOTE: Traps not run in series.

Inspection of the trap contents after termination of each experiment revealed that the particles remained intact with only little dusting.

Charcoal: Disposal traps constructed of Monel were used to evaluate charcoal as a fluorine disposal reagent. Initial experiments were conducted using ground "household" charcoal briquettes. During fluorine consumption, sharp pressure rises were noted, and charcoal dust was later found upstream from the disposal traps.

A check valve was installed on the inlet side of the traps, and each trap was filled with approximately 200 grams of Cliffs-Dow charcoal. A layer of Monel chips was placed above and below the charcoal to prevent charcoal dust. from entering the system.
In those experiments where greater than 32 moles of fluorine was disposed, almost all the charcoal in the first trap was consumed. Only slight pressure rises were observed when Cliffs-Dow charcoal was used, and the check valve prevented any pressure rises from interfering with the system.

In two of the five charcoal experiments, over 32 moles of fluorine were disposed of before line plugging occurred. The plugging was believed caused by the dusting of reacted Monel chips. In the last experiment, tabular alumina balls were used instead of Monel chips. This, resulted in maximum fluorine disposal, and the alumina balls appeared intact after use.

The temperature of the charcoal-fluorine reaction is shown in Figures 2 and 3 . The temperature rise was rapid and a function of fluorine flow rate. The trap wall temperature rarely exceeded $200^{\circ} \mathrm{C}$ and no overheating problems were encountered.

Figure 2. Typical fluorine-charcoal reaction temperature versus fluorine flow-rate and fluorination time.

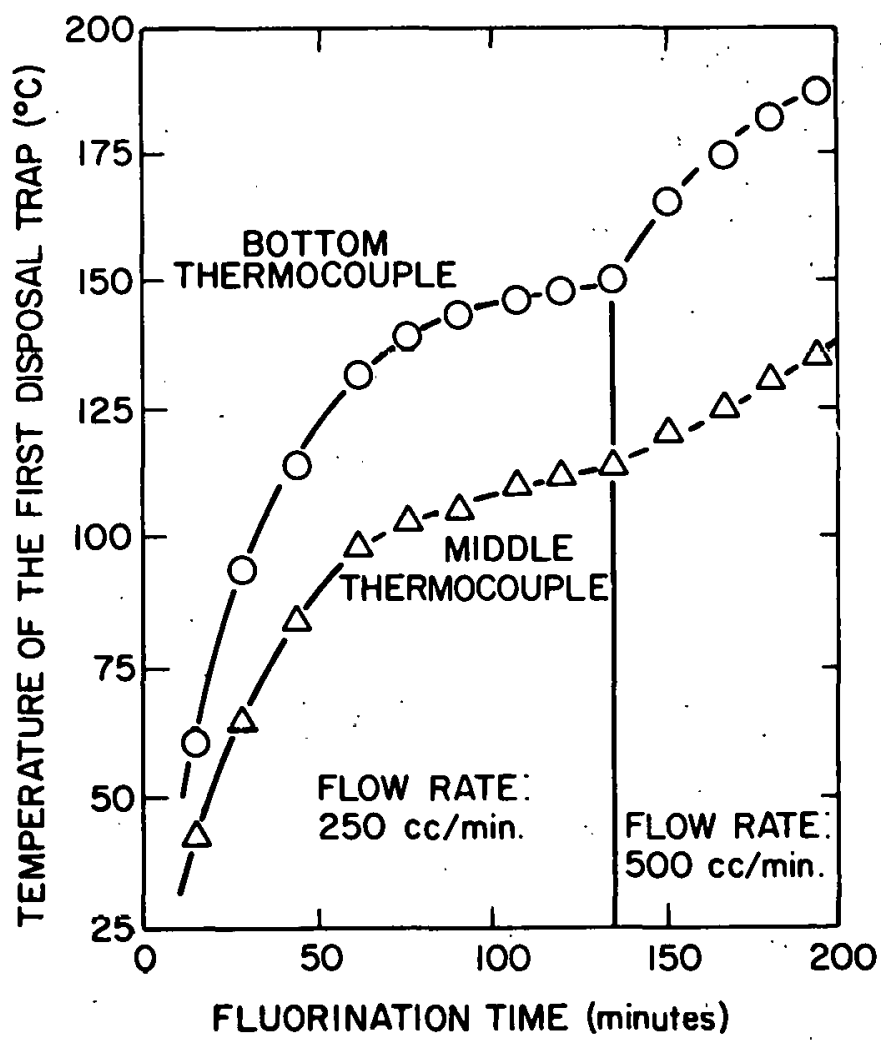




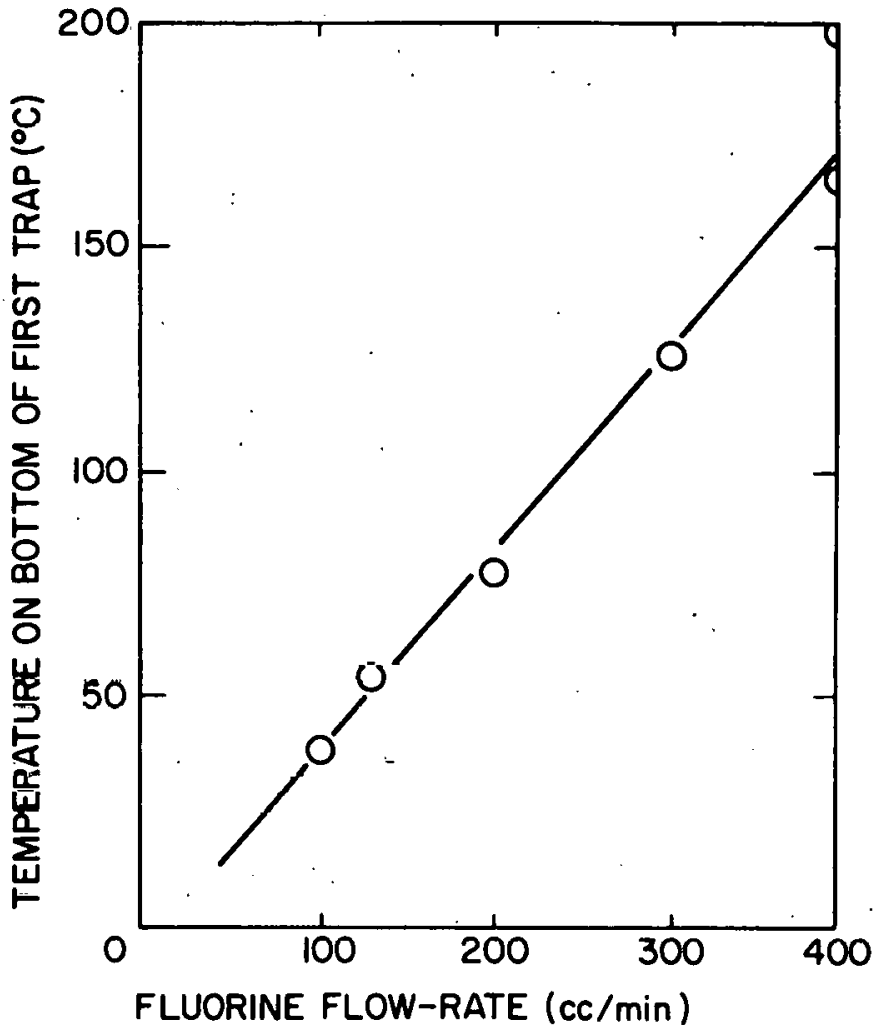

Figure 3. Maximum fluorine-charcoal reaction temperature versus fluorine flow-rate within $\mathbf{3 0}$ minutes.

\section{REFERENCES}

1. A. N. Koehulkov, Improving the Methods of Adsorption of Gases in Fluorite Ovens, Trans. Sci. Inst. Fertilizers and Insectofungicides U.S.S.R., No. 123, 168-74 (1935); Chem. Abstr. $30,3600^{5}$ (1936).

2. Metallgesellschaft A.-G., Removal of Fluorine, Chlorine, and Other Contact Poisons by Washing of Gases to be Electrically Dearseniated, Belg. Patent 449,725, (1943); Chem. Abstr. 41, 7065c (1947).

3. I. N. Kuz'minykh, E. L. Yakhontova, and E. I. Ermakova, Purification of Gases from Fluorine by Washing on Bubbling Plates, Nauch Tekl. Inform. Bull. Nauch. Inst. po Udobren. $i$ Insektofungitsidam. No. 9, 22-9 (1958); Chem. Abstr. 54, 10208 (1960).

4. F. G. Heil, R. D. Young, and J. J. Stumpe, Pilot Plant Study of an Ammonium Fluoride Process for Recovery of Fluorine from Superphosphate, J. Agr. Food Chem. 9, 459-69 (1961).
5. P. Kerenyi and D. Ivami, Fluorine Balance in the Production of Superphosphate, Chem. Prumysl 13, 403-05 (1963); Chem. Abstr. 60, $1359 \mathrm{~g}$ (1964).

6. Reprocessing. of Irradiated Fuels, Quarterly Report No. 21, April 1 - June 30, 1965. EURAEC-1536, Mol, Belgium, 1965.

7. R. Heremans, J. Broothaerts, C. Lambiet, and M. Put, Research and Studies Relative to the Hot Semi-Pilot Plant, ORNL-tr-1121, Mol, Belgium, 1966.

8. P. E. Hynson and W. R. Mustian, Jr., Gas Sr.ruhhing Prneess and Apparat.ns, U. S. Patent. 3,302,372, (1967); Chem. Abstr. 66, 77834v (1967).

9. V. W. Slabey and E. A. Fletcher, Rarie of Reaction of Gaseous Fluorine with Water Vapor at $35^{\circ}$, Natl. Advisory Comm. Aeronaut. Tech. Note 4374, 1958; Chem. Abstr. 53, 2752 (1959).

10. R. C. Downing, A 1,500-AMP Cell for Fluorine Generation, in C. Slesser and S. R. Schram, Preparation, Properties, and Technology of Fluorine and Organic Fluoro Compounds, pp 70-76, McGraw-Hill Book Co., New York, 1951.

11. C. H. Cady, Reaction of Fluorinc with Water and Hydroxides, J. Am. Chem. Soc. 57, pp 246-9 (1935).

12. I. G. Farbenind. A.-G., Fluorine Compounds, Fr. Patent 806, 568, (1936); Chem. Abstr. 31, $4779^{\circ}$ (1937).

13. C. R. Schmitt, Reaction of Fluorine with Steam at Elevated Temperatures, K-892, Oak Ridge, Tenn., 1952; NSA 6, 3244 (1952).

14. S. H. Smiley and C. R. Schmitt, Continuous Disposal of Fluorine, lnd. Eng. Chem. 46, pp 244-47 (1954).

15. W. B. Burford, III, and H. C. Anderson, Method of Disposing of Corrosive Gases, U. S. Patent 2,515,112, (1950); NSA 4, 5794 (1950).

16. W. B. Burford, III, and J. M. Hamilton, Jr., Disposal of Fluorine by Caustic Scrubbing, in C. Slesser and S. R. Schram, Preparation, Properties, and Technology of Fluorine and Organic Fluoro Compounds, pp 198-203, McGrawHill Book Co., New York, 1951. 
17. J. B. Ruch, VPP-Design Criteria for an Installation to Remoive Hydrogen Fluoride and Fluorine from the Cells 1 and 2 Ventilation Gases Prior to Filtration, CF-60-4-38, Oak Ridge, Tenn., 1950.

18. R. Landau and R. Rosen, Fluorine Disposal Continuous Process, Ind. Eng. Chem. 40, pp 1389-93 (1948).

19. F. J. Maier, Regenerating the Hydroxyapatite of Tricalcium Phosphate and Trimagnesium Phosphate for Use as Fluoride Adsorbent Reagents, U. S. Patent 2,553,595, (1951); Chem. Abstr. 45, 6776d (1951).

20. G. G. Joris and C. D. Compton, The Absorplion of Fluorine and Uranium Hexafluoride by Sodium Carbonate Solutions, AECD-3892, Princeton Univ., N.J., 1946.

21. F. Fichter and A. Goldach, Oxidation with Fluorine, XIX. Action of Fluorine on Aqueous Solutions of Ammonia and Ammonium Carbonate, Helv. Chem. Acta. 15, 1511-20 (1932).

22. A. Rapko, O. Sabo, and P. Gubric, Selective Trapping and Recovery of Fluorine from Waste Gases, Czech. Patent 121, 428, (1966); Chem. Abstr. 67, 111227g (1967).

23. O. Ruff and O. Bretschneider, The Reaction Products of the Various Forms of Carbon with Fluorine, Part II. Carbon Monofluoride, Z. Anorg. u. Allgem. Chem. 217, 1-19 (1934); Chem. Abstr. 28, $.2286^{\circ}$ (1934).

'24. J. H. Simons and L. P. Block, Fluorocarbons. The Reaction of Fluorine with Carbon, J. Am. Chem. Soc. 61, 2962-66 (1939).

25. W. Rudorff and G. Rudorff, Tetracarbon Monofluoride, A New Graphite-Fluorine Compound, Chem. Ber. 80: 417-23 (1947); Chem. Abstr. 43, 2107e (1949).

26. W. N. Hubbard and H. M. Feder, Calorimetry, in Chemical Engineering Division Semiannual Keport January-June, 1964, pP 221-31, ANL-6900, Argonne, Ill., 1964.

27. E. Grcenberg, C. A. Natke, and R. Terry, Combustion of Silicon Carbide and Graphite in Fluorine, in Che mical Engineering Division Semiannual Report July-December, 1964, pp 177-79, ANL-6925, Argonne, ill., 1964.
28. A. K. Kuriakose and J. L. Margrave, Kinetics of the Reactions of Elemental Fluorine. IV. Fluorination of Graphite, J. Phy. Chem. 69, 2772-75 (1965).

29. R. J. Rollbuhler, The Disposal of Fluorine, in L. E. Bollinger and A. W. Lemmon, Jr., Proceedings of the Propellant Thermodynamics and Handling Conference, pp 259-66, Held at Ohio State University, Columbus, Ohio, 1959.

30. H. W. Schmidt, Reaction of Fluorine with Carbon as a Means of Fluorine Disposal, NASA-RME57E02, Cleveland, Ohio, 1957; NSA 12, 4726 (1958).

31. H. W. Schmidt, Design and Operating Criteria for Fluorine Disposal by Reaction with Charcoal, NASA-M-1-27-59E, Cleveland, Ohio, 1959; NSA 13, 14231 (1959).

32. N. W. Houston, Fluorine Disposal Using Charcoal, GAT-T-819, Portsmouth, Ohio, 1960.

33. J. T. Holmes and C. B. Schoffstoll, Disposal of Gaseous Fluoride Volatility Reagents, Chemical Engineering Division Semiannual Report, JanuaryJune 1966, pp 125-28, ANL-7225, Argonne, Ill., 1966.

34. A. V. Crewe and S. Lawroski, Disposal of Gaseous Fluoride Volatility Reagents, Reactor Development Program Progress Report, September 1966, p 89, ANL-7255, Argonne, Ill., 1966.

35. R. Landau and R. Rosen, Industrial Handling of Fluorine, in C. Slesser and S. R. Schram, Preparation, Properties, and Tochnology of Fluorine and Organic Fluoro Compounds, pp 153-57, McGraw-Hill Book Co., New York, 1951.

36. R. C. Lumatainen and M. Levenson, Absorption of Some Halogen Gases from Air by a Limestone Bed and Spray Tower, ANL-5015, Argonne, Ill., 1953.

37. T. P. Hignett and M. R. Siegal, Recovery of Fluorine from Stack Gases, Ind. Eng. Chem. 41, 2493-98 (1949).

38. Metallgesellschaft A.-G., Removing Fluorine from Roasting Gases, Fr. Patent 853,303, (1940); Chem. Abstr. 36, 23949 (1942). 
39. R. Kaack and R. Deplanque, Utilization of $\mathrm{SiO}_{2}$ Obtained as By-Product in the Preparation of Superphosphate, Ger. Patent 724,343 (1942); Chem. Abstr. 37, 5824² (1943).

40. R. P. Bell, A Fluidized Bed of $\mathrm{UF}_{4}$ for Removal of $U F_{6}$ and $F_{2}$ from a Dilute Gas Stream, GAT-298, Portsmouth, Ohio, 1960.

41. W. R. Pedigo, C. R. King, L. A. Dean, J. E. Owen, and S. Bernstein, Fluidized Bed Recovery of Fluorine in the Manufacture of $\mathrm{UF}_{6}$, Chem. Eng. Progr., Symp. Ser. Pt. 15 62, 12-19.(1966).
42. J. T. Holmes, Versatile Scrub Tower Removes Halogen Off-Gasses, Chem. Eng. 68, 94-96 (1961).

43. S. G. Turnbull, A. F. Benning, G. W. Feldmann, A. L. Linch, R. C. McHarness, and M. K. Richards, Analysis and Disposal of Fluorine, Ind. Eng. Chem. 39, 286-8 (1947).

44. G. Long, An Apparatus for the Disposal of Fluorine on a Laboratory Scale, AERE-C/M-260, Harwell, Berks, England, 1955. 